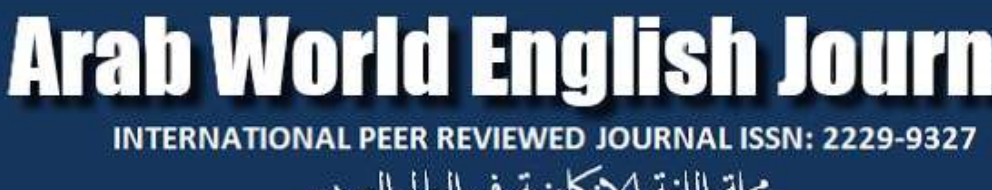 \\ بجاة اللفة الوكليزية في العالم العربي
}

Arab World English Journal (AWEJ) Volume 8 Number 2 June, 2017

DOI: https://dx.doi.org/10.24093/awej/vol8no2.7

Pp. 101- 118

\section{A Program to Develop the Students' Awareness of E-learning and its Applications in} English in the Foundation Program of Dhofar University

\author{
Sobhy Ahmed Soliman \\ College of Arts and Applied Sciences \\ Dhofar University, Salalah, Oman
}

\author{
Ashry Abdallah Mahmoud Waziry \\ Foundation Program, Dhofar University \\ Salalah, Oman
}

\begin{abstract}
This study aims to identify the degree to which English language students in the Foundation Program at Dhofar University, Oman are aware of e-learning and its applications in their field of specialization. It further attempts to identify the effectiveness of certain patterns and tools of elearning in student performance, using both descriptive and experimental approaches. To achieve these goals, researchers use a scale to measure the awareness of e-learning that includes twentyfive multiple choice questions and an evaluation card on e-learning applications in English. The study sample consists of sixty male and female students at the university. There are two primary outcomes. First, the degree of student awareness of English language e-learning is found to be relatively weak, with statistically significant differences in awareness among male and female students in favor of females. There are further statistically significant differences between students' average scores before and after the development of an e-learning awareness program in favor of post application. The study makes a number of recommendations, including adopting the pilot awareness program in all majors and holding e-learning training seminars for both faculty and students, which, it is hoped, will bolster the effectiveness of e-learning at the university.
\end{abstract}

keywords: Awareness, E-learning, English language, foundation program

Cite as: Soliman, S. A., \& Waziry, A. A.M. (2017). A Program to Develop the Students' Awareness of E-learning and its Applications in English in the Foundation Program of Dhofar University. Arab World English Journal, 8 (2). DOI: https://dx.doi.org/10.24093/awej/vol8no2.7 